
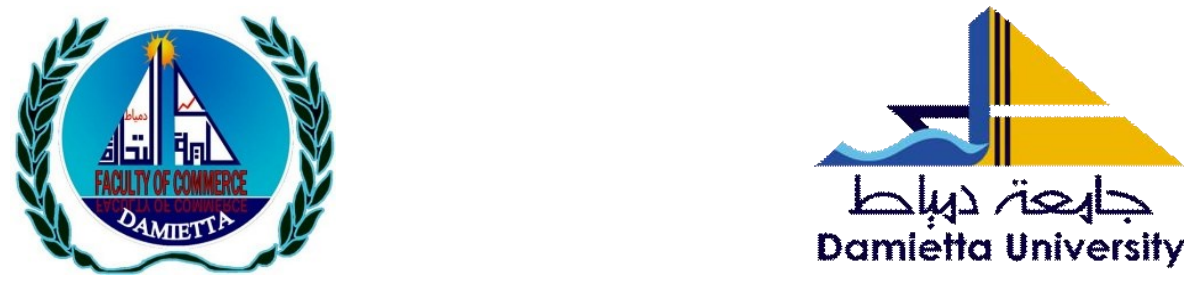

\title{
Current Year Audit Opinion and Next Year Audit Fees: Does Family Ownership Matter?
}

\author{
Prepared by \\ Hebatallah Abd El Salam Badawy \\ Assistant Professor of Accounting and Auditing \\ Faculty of Commerce - Alexandria University \\ Associate Professor of Accounting and Auditing \\ Faculty of International Business and Humanities \\ (FIBH) \\ Egypt Japan University of Science and Technology \\ (E-JUST) \\ Heba782001@yahoo.com \\ Heba.badawy@ejust.edu.eg \\ Scientific Journal for Financial and Commercial Studies and \\ Researches (SJFCSR) \\ Faculty of Commerce - Damietta University \\ Vol.2, No.1, Part 1., Jan. 2021 \\ Badawy, H. A. E. (2021). Current Year Audit Opinion and Next Year \\ Audit Fees: Does Family Ownership Matter? Scientific Journal \\ for Financial and Commercial Studies and Researches \\ (SJFCSR), Vol.2 (1) Part1. pp.643- 683.
}

\section{APA Citation:}

Website: https://cfdj.journals.ekb.eg/ 


\title{
Dr. Hebatallah Badawy
}

\begin{abstract}
The paper aims to investigate the association between current year audit opinion and the pricing of the next year audit mission and whether this relationship differs with different nature of ownership (family - nonfamily) in the Egyptian setting. Using a sample of 358 firm-year observations from the Egyptian Stock Exchange (EGX hereafter) over the period 2016-2019, ordinary least square (OLS) regression models are estimated to test the research hypotheses and conduct sensitivity and additional analyses. The author didn't find significant association between current year audit opinion and next year audit fees. However, if the auditor issues a qualified audit opinion for a family firm, he will ask for a fee premium for the next year audit mission. Results are robust to alternative measures of next year audit fees and current year audit opinion. The paper uses the current year audit opinion as an input to the next year audit pricing decision. The paper responds to previous calls to investigate the relationship between audit fees and type of audit opinion and the impact of family ownership on audit fees. In addition, this study uses three alternative measures of next year audit fees and an alternative measure of current year audit opinion. Finally, this study adds evidence to the corporate governance literature in developing countries.
\end{abstract}

Keywords: Audit fees, audit opinion, family ownership, Egypt.

\section{Introduction}

Following the corporate scandals worldwide, more attention was paid to audit quality and auditors' independence and stricter rules were set on the provision of non-audit services to enhance the auditors' independence level and prevent the recurrence of such scandals in the future. More emphasis was put on the audit opinion and the auditors' fees, which are one of the most important factors that may affect their independence level. 


\section{Dr. Hebatallah Badawy}

Auditor's opinion on the financial statements, which is the output of the audit process is important from the auditor's, entity managers' and users of financial statements' point of view, who want to take different investment and credit decisions (Crucean, 2019). Several studies (Tahinakis and Samarinas, 2016; Crucean, 2019; Kaplan et al., 2020) investigated the information content of audit opinion and how it might affect the users of financial statements. Despite the importance of audit report and opinion from the auditor's point of view, up to my knowledge, no prior research investigated the effect of current year audit opinion on auditor's decisions in the future; for instance, the pricing of future audit missions.

Meanwhile, according to $\mathrm{Ng}$ et al. (2018), understanding how audit fees are determined is very important. Audit fees are related to audit effort (Zhang, 2018) and are a function of the client's financial reporting system (Simunic, 1980). Prior research has focused intensively on the audit pricing process and the determinants of audit fees. According to Simunic (1980) and Smith et al. (2019), audit fees are a function of audit effort required to provide reasonable assurance that the financial statements as a whole are free from material misstatements, normal profits, fee premiums and the expected loss that may arise from litigation. In addition, auditors must consider clients' risks in their pricing decision (Nikkinen and Sahlstrom, 2003). According to the agency theory, which explains the relationship between management and owners, companies may demand higher audit quality and pay higher audit fees to reduce agency costs that might result from the management-owner conflict of interests (Francis, 1984).

According to ISA315, auditors are required to identify and assess the risk of material misstatements, whether they are to fraud or error, through the entity and the environment in which it works in order to design and implement suitable responses to these assessed risks. The risk of material misstatements might be affected by the nature of industry in which the audit client operates, its going concern status, profitability, complexity of transactions and ownership structure (Myoli, 2020). 


\section{Dr. Hebatallah Badawy}

The auditing environment in Egypt is unique. It is known with its weak litigation risk and weak investor protection. Big4 audit firms are present in Egypt and audit firms that are affiliated to the Big4 are known with their higher audit quality and audit fees (El-Dyasty, 2017). In addition, most auditors in Egypt are offering audit and non-audit services, such as tax and consulting services to their audit clients. Also, auditors in Egypt are inclined to issue unmodified audit opinion (El-Dyasty, 2017). Next year audit fees are usually determined in the General Shareholders' meeting, which is held to approve the auditor's report on the last year financial statements. Accordingly, Egypt, as a developing country, is a good research environment and it is important in this unique environment to examine the audit pricing decision and the factors that may affect such decision. It is important to investigate the impact of issuing current year qualified audit opinion on next year audit fees and how family ownership might affect the latter relationship.

Based on the call of Hay et al. (2006) to investigate the effect of family ownership on audit fees and that of Caneghem (2010) to examine the association between audit fees and the type of audit opinion, the objective of this paper is to test the impact of issuing a qualified audit opinion on the current year financial statements on the audit fees of the next year in the Egyptian setting, and how this impact might differ in case the auditee is a family firm. To fulfil this objective, the author relied on a sample of 358 firm-year observations from EGX during the period from 2016-2019. Based on the OLS regression results, the author didn't find significant relationship between current year qualified audit opinion and next year audit fees, however it was found that this association differs when the firms audited are family firms. Results show that auditors will ask for higher audit fees to audit the next year financial statements when they issued a qualified audit opinion to family firms. 


\section{Dr. Hebatallah Badawy}

The importance of this study stems from the importance of investigating one of the most important factors that affect auditors' independence level, which is audit fees. This study is different from prior studies conducted in the area of audit fees, as it investigates how the issuance of qualified audit report on the current year financial statements might affect the value of the next year audit fees. This paper contributes to the literature in three ways. First, it documents empirical evidence of the association between current year qualified audit opinion and audit pricing decision concerning the next year financial statements. Second, as the impact of family ownership on audit fees remains understudied, this paper provides evidence of the impact of family ownership on the relationship between current year audit opinion and future audit pricing decision. Third, this paper adds to the current corporate governance literature in developing countries.

The remainder of this paper will be organized as follows: the literature on audit fees determinants, relationship between audit opinion and audit pricing and the impact of family ownership is discussed in Section 3, and the research hypotheses are developed. Sample selection, descriptive statistics and empirical results are presented in Section 4. Section 5 concludes and provides implications for future research.

\section{Literature Review and Hypotheses Development}

\subsection{Determinants of audit fees}

Extensive research was conducted in different countries to examine the main determinants of audit fees. Those determinants lie in three main categories; firm related attributes, auditor related attributes, and engagement related attributes (Hay et al., 2006; Hay, 2013).

Despite the extensive research on the determinants of audit fees that are held in different countries, results were inconclusive. For instance, in Jordan, Naser and Nuseibeh (2007) used a sample of 181 companies listed on Amman Stock Exchange and found that firm size and auditor status, industry type, firm complexity and risk are the main determinants of audit fees. Using a sample of 272 companies of the top 300 publicly listed companies in Australia, Singh and Newby (2010) found that internal audit is positively associated with audit fees. In US, Harjoto et al. (2015) 


\section{Dr. Hebatallah Badawy}

examined a sample of 12,153 observations from 1,642 firms during the period from 2000-2010 and found that firms with female and ethnic minority CEOs ask for higher audit fees.

To examine the effect of auditor's experience on audit fees in China, Cahan and Sun (2015) investigated a sample of 1,917 firm-year observations over the period 2007-2010 and found positive association between auditor's experience and audit fees. In Indonesia, Rusmanto and Waworuntu (2015) found that client size is the main factor affecting audit fees, however complexity, profitability, audit quality and number of subsidiaries are not significantly associated with audit fees. On the other side, Akpom (2016) examined a sample of 141 companies listed on Nigeria Stock Exchange in 2013 and concluded that company size, profitability, complexity, riskiness, foreign activity level and audit firm size are main predictors of audit fees.

Focusing on another internal audit perspective, Alzeban and Sawan (2016) on gathered data from annual reports and based on the responses of 229 chief internal auditors from companies listed on London Stock Exchange, the authors found that adherence to International Standards for the Professional Practice of Internal Auditing is associated with higher audit quality and audit fees. In Japan, Hossain et al. (2017) found evidence that the number of senior auditors, assistant auditors and other professional staff has a significant positive effect on audit fees based on a sample of 3,981 firm-year observations during 2007-2011.

During the past two years, researchers focused extensively on the determinants of audit fees. In India, Rani (2018) investigated the association between audit committee effectiveness and audit fees. Based on a sample of 1,410 firm-year observations of listed companies in S\&P Bombay Stock Exchange during 2007-2012, the author found that audit committee size and independence, company size, age, risk and audit firm size are positively related to audit fees. However, leverage and market value of firm divided by book value of assets are negatively related to audit fees. In a recent study that examined a factor that might affect future audit fees, Yen et al. (2018) examined whether information security breaches have a significant effect on the next year audit fees and whether this 


\section{Dr. Hebatallah Badawy}

association is affected by audit firm industry expertise, size and auditor tenure. Based on a sample of 22,467 firm-year observations in US, the authors found that information security breaches have a significant positive effect on audit fees. However, the audit firm characteristics that help the auditors to understand the effect of information security breaches negatively moderate the positive association between information security breaches and audit fees.

In U.S., Paredes and Wheatley (2019) investigated the effect of changing fiscal year ends on audit fees and audit quality. Based on a sample of 223 firms that changed their fiscal year ends during the period from 2004-2014, the authors found that changing fiscal year ends to a nonbusy season, audit fees and efforts will be significantly reduced. In U.S. also, Barua et al. (2019) examined the effect of two types of leverage; operating liability leverage and financial leverage on audit fees. Based on a sample of 38,118 firm year observations of U.S. companies during the period 2004-2016, the authors found that operating liability leverage is positively associated with audit fees, while financial leverage is negatively associated with audit fees.

From another perspective, Bicudo de Castro et al. (2019) investigated the impact of annual report tone on audit fees. Based on a sample of 5,034 firm-year observations of firms listed on the Australian Stock Exchange during the period from 2002-2014, the authors found that positive tone of annual reports is associated negatively with audit fees.

In India, Bhattacharya and Banerjee (2020) examined the determinants of audit fees and the effect of financial distress on audit pricing. Based on a sample of 22,644 firm year observations of Indian firms during the period from 1990-2015, the authors found that audit fees are positively associated with affiliation to Big4 audit firms, have industry specialization and offering audit and non-audit services. 


\section{Dr. Hebatallah Badawy}

It is clear from discussing the prior literature on audit fees, that there is great attention paid to the importance of audit fees and the determinants used to price audit services. Prior literature focused on the determinants of audit fees from different perspectives; the audit firm's perspective, such as audit firm size, affiliation to international firms, auditor experience and specialization, audit team composition and auditor tenure. Another perspective is that of the client, which includes corporate governance issues, such as internal audit competencies and characteristics of the audit committee and board of directors, in addition to client size, operating and financial risk, industry, profitability and complexity. Final perspective is that of the engagement, which includes provision of nonaudit services, busyness and audit report lag. Despite the extensive literature on audit fees, inconclusive results were reached.

\subsection{Audit opinion and audit fees}

Formulating an audit opinion is a complex process that involves evaluating client acceptance or retention decisions, understanding the clients' business, making internal control checks, collecting evidence based on substantive tests of transactions and balances and forming an opinion based on the aggregated results and evidence collected (Felix and Kinney, 1982). Auditor's opinion on the financial statements, which is the final outcome of the audit process, is important from the auditor's, entity managers' and users of financial statements' point of view (Crucean, 2019). Audit reports provide useful information for investors and it was proven that unqualified audit opinion with explanatory paragraph on financial distress and going concern opinion help in reducing information uncertainty (Kaplan et al., 2020). In addition, the reason for modified audit opinion may be a reference for future auditors' missions (Crucean, 2019).

Concerning the factors that may affect auditors' opinion, they can be classified into four main categories: client related characteristics, such as firm size, risk and corporate governance, audit firm characteristics, such as audit firm size and auditor specialization, engagement characteristics, such as audit fees and auditor tenure and finally institutional factors, such as litigation and investor protection (Zhang, 2018). 


\section{Dr. Hebatallah Badawy}

Prior research investigated the association between audit fees and audit opinion from different perspectives and reached different results. Based on a sample of 185 Greek companies listed on the Athens Stock Exchange, Caramanis and Spathis (2006) didn't find significant association between audit fees and the probability to issue qualified audit opinions. In Malaysia, Che Ahmad et al. (2006) examined a sample of 819 listed companies in 2002 and found a positive and significant association between non-audit fees and audit fees and that non-audit fees are significantly associated with the auditor's opinion.

Using audit opinion as a control variable, Kharuddin et al. (2019) examined the association between partner industry specialization and audit fees in UK. Based on a sample of 680 firm-year observations related to companies listed on London Stock Exchange during the period from 20092011, the authors found positive but insignificant relationship between audit opinion and audit fees. Using audit opinion also as a control variable, Shan et al. (2019) investigated the association between managerial ownership and audit fees. Based on a sample of 6,158 firm-year observations of Australian listed firms during the period from 2005-2015, the authors didn't find significant relationship between having modified audit opinion issued a year before and the audit fees.

In the same context, prior research investigated the association between audit fees and adding an additional paragraph in the audit report. Bedard et al. (2019) investigated the impact of adding an explanatory paragraph (justification of assessments) to the audit reports in France on investors and audit (audit delay, audit fees and audit quality). Using a sample of 1,250 firm-year observations, the authors found that the implementation of this requirement hasn't significant effect on audit fees. consistently, Reid et al. (2019) investigated the impact of applying new reporting regime; adding critical audit matters in the audit report on financial reporting quality, audit fees and audit delay in UK. The authors hypothesized that adding critical audit matters to the audit report will make auditors more accountable and will require more audit time and effort and 


\section{Dr. Hebatallah Badawy}

sometimes require training costs. The authors found that the new reporting regime has a positive impact on financial reporting quality, however it has no significant association with audit cost to the client in the form of audit fees or audit cost to the market in the form of audit delay

In a recent study, Xiao et al. (2020) noted that higher audit effort might result in deeper understanding of the client's operations and will increase the possibility of detecting material misstatements and in turn the issuance of modified audit opinion. On the other side, this deeper understanding will enhance the communication between the auditor and the client and will lead to detecting misstatements that will be modified and adjusted and so there is no need to issue modified audit opinion. Based on a sample of 7,833 firm-year observations during the period 2006-2011 from China Stock Market, the authors didn't find significant association between audit effort and issuance of modified opinion.

It is clear from the discussion above that despite the extensive research that examined the relationship between audit fees and audit opinions, most of them focused on how audit fees affect the type of audit opinion and not how the audit opinion and report already issued might be an input in the audit pricing decision for the next year audit mission. For instance, if the firm received a modified audit opinion in the previous year, auditors may decide to invest more audit effort in order to decrease audit risk (Cao et al., 2015). In addition, prior research reached mixed results. Some studies didn't find significant association between audit fees and audit opinion, whether it is a qualified audit opinion or a clean opinion with a matter of emphasis paragraph. Other research found positive association between audit fees and audit opinion.

\subsection{Family ownership and audit fees}

To examine the effect of family ownership on audit fees, it is important to highlight two types of agency problems that result from the separation between owners and management (Type I and Type II agency problems). Type I agency problem results between managers and shareholders. According to the alignment effect hypothesis, family owners 


\section{Dr. Hebatallah Badawy}

are less likely to have such a problem because of their involvement in management and their monitoring role and they tend to forgo short term benefits for long term gains with their objective to pass their business to the future generations (Francis, 1984; Tee, 2018). Type II agency problem appears between small and large shareholders. According to the entrenchment effect hypothesis, family owners are more likely to suffer from this problem because of the probability of being involved in activities that are beneficial to them but harmful to other or minority shareholders (Ho and Kang, 2013; Tee, 2018). According to type I agency problems, family owners are less likely to hire big audit firms because of the direct monitoring of family owners. On the other side, according to type II agency problem, family owners are more likely to hire big audit firms in order to send a message on their credibility to other shareholders.

Hay et al. (2006) called for more research on the effect of family ownership on audit fees, as family firms are of special and important ownership structure and have different agency problems (Ho and Kang, 2013). After this call, more research was directed towards investigating the impact of family ownership on audit pricing decision. In Bangladesh, Khan et al. (2011) argued that family firms might limit some executive positions for family members, who take the decisions for their own interests. In this case, financial reporting might be affected and auditors might prefer to charge those firms higher audit fees because they may exert more efforts to reduce the related audit risks. Based on a sample of 183 firm-year observations from 2003-2005 of listed companies, the authors found significant and negative relationship between family ownership and audit fees., which indicates the low demand of higher audit quality by family firms. Consistently, Ho and Kang (2013) found evidence that family firms incur lower audit fees, in comparison with other firms. This result is more pronounced when family owners are active shareholders. On the other hand, Ben Ali and Lesage (2013) used sample of 476 firm year observations from listed companies on the SBF 250 French index during the period 2006-2008 and found no significant relationship between family 


\section{Dr. Hebatallah Badawy}

ownership and audit fees. In U.S., Ben Ali and Lesage (2014) examined a sample of 3,291 firm-year observations of U.S. Listed firms during the period from 2006-2008 and found a negative and significant association between family shareholdings and audit fees.

On the other side, Tee (2018) examined a sample of 3,787 firmyear observations from Malaysian Stock Exchange during the period 20022015 and found a significant positive association between family ownership and audit fees. This relation is pronounced with older family firms and higher family shareholdings. In addition, this association is stronger when family firms are politically connected.

Consistent with Ho and Kang (2013) and Ben Ali and Lesage (2014), Al-Okaily (2020) examined the association between family control and involvement in management and audit fees in normal economic conditions and during crisis period. The author collected data from 1,346 firm-year observations from firms listed on London Stock Exchange in UK firms during the period from 2005-2013 and found that during normal economic conditions, family ownership and involvement are associated with lower audit fees. During such periods, family members are practicing their monitoring role and substituting the qualified auditors' role and so don't seek higher audit quality services. However, during crisis period, family firms ask for higher audit quality services because of the expropriation of family to minority shareholders' wealth and so the effect on audit fees tend to be reversed.

It is clear from reviewing and analyzing prior studies that in general, family ownership has a significant effect on audit pricing. According to the alignment effect hypothesis, family members will monitor their business effectively and audit risk will be assessed at a low level. Accordingly, audit fees are expected to decrease. However, according to the entrenchment effect hypothesis, family members may achieve gains on the expense of others and so will ask for a higher quality audit and auditors will ask for a fee premium. 


\section{Dr. Hebatallah Badawy}

\subsection{Development of research hypotheses}

Based on the prior discussion, it can be noticed that in general, researchers paid a considerable attention to the determinants of audit fees and the impact of family ownership. In Egypt, audit fees are now publicly available, especially for firms listed on EGX, for the purpose of reducing information asymmetry and increasing the level of transparency in order to help investors and other stakeholders take rational decisions.

In Egypt, auditors whether those affiliated to Big4 or Non-Big4 must issue their audit reports within three months after the financial statements date. According to Companies Law No. 159/1981, during the General Shareholders' meeting which is held to discuss the auditor' report in the presence of the board of directors and audit committee members and the representatives of the shareholders, the auditor presents his audit report and discuss it. Once it is approved by the council, certain decisions related to the auditor are taken, for instance the change of the auditor or audit firm and the next year audit fees. During this meeting, the auditor presents his proposal for the next year audit fees and then a decision was taken; whether to accept this proposal or to set another amount of next year audit fees.

The question here is: what is the effect of issuing a qualified audit opinion on the auditor's assessment of client business risk and the pricing of the next year audit mission? And what about if the audit client is family owned, does this ownership structure affect the relationship between current year qualified audit opinion and next year audit fees?

Concerning the impact of current year qualified audit opinion, it is expected that audit reports are value relevant and has information content and qualified audit opinion will have a negative impact on investors (Hakim et al., 2012). It is expected that the issuance of qualified audit opinion is a result of careful audit process and crucial investigations and serious of discussions and meetings with management to make the audit adjustments. This indicates also that the issuance of qualified audit opinion is significantly related to audit efforts and in turn to audit fees. It is expected that the issuance of a qualified audit opinion implies higher audit risk, which is expected to be held to the future. According to Habib (2013), current year audit opinion is positively associated with next year audit 


\section{Dr. Hebatallah Badawy}

opinion, and it is expected that the reason for modified audit opinions may act a reference for future audit missions (Crucean, 2019). This means that the auditor will consider his prior opinion and the reasons for this qualified opinion when he prepares his proposal of the next year audit fees. Accordingly, it is expected that current year qualified audit opinion will have a positive impact on auditor's fees for the next year financial statement audit. Based on this argument, the first research hypothesis can be developed as follows:

H1: ceteris paribus, current year qualified audit opinion has a significant positive association with next year audit fees

In Egypt, there are family firms that are listed on EGX. Family firms are of different nature and agency problems. According to the alignment effect hypothesis, it is expected that family members who are engaged in management will work for the sake of the company and will sacrifice for the future generations. According to this hypothesis, agency problems will decrease. In addition, the information asymmetry level between managers and shareholders is low, making auditors evaluate audit risk at a low level. Accordingly, family members will not ask for higher audit quality to reduce agency costs and will go for non-big4 firms and so the audit fees will be lower. On the other side, according to the entrenchment effect hypothesis, family members may work for their own benefits on the expense of minority shareholders, and in this case agency problems will exist. Here it is expected that family members might ask for higher quality audits and will go for Big4 audit firms and pay higher audit fees. According to this hypothesis, it is expected that family ownership in general will have a significant negative effect on audit fees.

Based on the discussion above, it is expected that family ownership will have a negative effect on next year audit fees, if family members monitor their business effectively. However, if family members work for their own interest on the expense of other shareholders and this is reflected on the financial reporting and auditors discover some problems, they will assess audit risk at a higher level will ask for higher quality audits and will pay higher audit fees. 
Accordingly, the second research hypothesis can be formulated as follows:

H2: ceteris paribus, the association between current year qualified audit opinion and next year audit fees differ significantly with different nature of ownership (family vs non-family)

\section{Research Design and Methodology}

In this section, the author will present the research methodology, sample selection procedures, measurement of independent, dependent, moderating and control variables used in the study and the derivation of research models.

\subsection{Sample and data}

This study focuses on non-financial firms listed on EGX during the period from 2016 - 2019. Financial firms are excluded from the study due to their different nature and special regulatory requirements. To reach the final sample, the author collected the data related to independent and control variables from the annual reports issued during the period from 2016 - 2019 and the data related to next year audit fees (dependent variable) from the minutes of General Shareholders' meetings held by the listed firms during the period from 2017 - 2020. After removing the observations with missing data and that which involve switching auditors, the final sample reached 358 firm-year observations (Table 1). Table (2) presents the distribution of the final sample by sector.

Table (1) Sample selection procedure

\begin{tabular}{|l|c|}
\hline Total firm-year observations from 2016-2019 & 880 \\
\hline Less: Observations in the financial industry & $(160)$ \\
\hline $\begin{array}{l}\text { Less: Observations with missing data and switching } \\
\text { auditors }\end{array}$ & $(352)$ \\
\hline Final sample & $\mathbf{3 5 8}$ \\
\hline
\end{tabular}


Dr. Hebatallah Badawy

\begin{tabular}{|l|c|}
\hline \hline \multicolumn{1}{|c|}{ Table (2) Sample distribution by sector } \\
\begin{tabular}{|l|c|}
\hline \multicolumn{1}{|c|}{ No. of firm-year } \\
observations
\end{tabular} \\
\hline Basic Resources & 16 \\
\hline Chemicals & 22 \\
\hline Construction and Materials & 51 \\
\hline Food and Beverages & 70 \\
\hline Healthcare and Pharmaceuticals & 33 \\
\hline Industrial Goods and Services and & 30 \\
Automobiles & 4 \\
\hline Media & 4 \\
\hline Oil and Gas & 16 \\
\hline Personal and Household Products & 70 \\
\hline Real Estate & 7 \\
\hline Retail & 2 \\
\hline Technology & 3 \\
\hline Telecommunications & 30 \\
\hline Travel and Leisure & $\mathbf{3 5 8}$ \\
\hline Total & \\
\hline
\end{tabular}

\subsection{Measurement of variables}

\subsubsection{Dependent variable: Audit fees}

LN(AUDIT_FEES): Natural logarithm of the next year audit fees (as mentioned in the General Shareholders' meeting minutes of the firms in the sample) (Ho and Kang, 2013; Yen et al., 2018; Tee, 2018; Bedard et al., 2019; Shan et al., 2019).

\subsubsection{Independent variable: Current year audit opinion}

AUDIT_OPINION: Dummy variable that takes the value (1) if the current year audit opinion is qualified, zero otherwise (Che Ahmad et al., 2006). 


\section{Dr. Hebatallah Badawy}

\subsubsection{Moderating variable: Family ownership}

FAMILY: Dummy variable that takes the value (1) if family ownership is more than $20 \%$ and at least one of the family members participates in management, zero otherwise (Khan et al., 2015).

\subsubsection{Control variables}

Following several prior studies, the author controlled for firm size, age, profitability, complexity and busy season. In the additional analysis, the author added an auditor related variable, which is audit quality.

Firm size (SIZE): Larger companies are engaged in more transactions. It is expected that large number of transactions will require more audit efforts and time, and in turn will be subject to higher audit fees (Che Ahmad et al., 2006). Following Singh and Newby, 2010 and Bedard et al., 2019, firm size is measured by the natural logarithm of the book value of total assets. Firm age $(A G E)$ : Tee (2018) called for investigating the impact of firm age on audit fees for family firms, that's why the author includes it in the study model. It is expected that older firms will be involved in more and complex transactions that will require more time and efforts from the auditors to complete their audits (Bhattacharya and Banerjee, 2020). Accordingly, it is expected that firm age will be associated positively with audit fees. Consistent with Xiao et al. (2020), firm age is measured by the natural logarithm of the number of years since the firm is established.

Firm profit (PROFIT): Firm profitability is measure of client risk (Caneghem, 2010). Prior research reached mixed results regarding the impact of firm's profitability on audit fees. There are three scenarios. The first one is that firms that reported losses will make auditors assess audit risk at a higher level and so will ask for higher audit fees. The second scenario is that firms that reported higher profits usually pay higher audit fees, assuming that higher profits require stricter and rigorous audit procedures to test the validity of the revenues and expenses recognition and this requires more effort and time (Joshi and Al-Bastaki, 2000). The third scenario is that firms that experienced losses paid lower audit fees than better performing ones, which might be because of putting pressure on auditors and preventing them from asking for higher audit fees (Niemi, 


\section{Dr. Hebatallah Badawy}

2002). Firm profitability will be measured by a dummy variable that takes the value (1) if net income is positive, zero otherwise.

Client Complexity (COMPLEXITY): More complex operations need more manpower and increase the auditors' efforts and in turn, this leads to higher audit fees (Nikkinen and Sahlstrom, 2005; Che Ahmad et al., 2006). Following Barua et al., 2019, Bedard et al., 2019 and Smith et al., 2019, complexity is measured by the percentage of receivables and inventory to total assets as those accounts are considered risky balance sheet components and require special audit procedures (Simunic, 1980; Caneghem, 2010; Hay, 2013). It is recommended to use both accounts as a proxy for inherent risk than examining each account separately (Hay et al., 2006).

Busy season (BUSY): auditors are known to have a busy season, which is the time where most of the companies issue their financial statements. Audits conducted during the busy season are considered costly, as they require more audit efforts and manpower (Hay et al., 2006). Although busy season is not frequently included in prior audit fees studies, but it is a main determinant of audit pricing ( $\mathrm{Ng}$ et al., 2018). In Egypt, December $31^{\text {st }}$ is the most common fiscal year-end. It is expected that audit firm will charge audit premium during their busy season. Consistent with Caneghem, 2010, Zhang, 2018 and Bedard et al., 2019, busy season will be measured by a dummy variable that takes the value (1) if the financial statement date is $31^{\text {st }}$ of December, zero otherwise.

In the additional analysis, audit quality (AUDIT_QUALITY) was added to the model to investigate its impact on audit fees. In Egypt, audit firms can be classified into two main categories; national and national audit firms affiliated to one of the Big4. It is expected that audit firms affiliated to one of the Big4 audit firms will charge their clients fee premiums because of their reputation, higher audit quality and their ability to indemnify losses for their clients' stakeholders (Hay et al., 2006; Jacob et al., 2019). Additionally, according to the "deep pocket" hypothesis, Big4 audit firms are wealthier than non-big4 audit firms and they have a lot of clients and so less dependent on their clients (Caneghem, 2010). Here, audit quality will be measured by the affiliation to one of the Big4 audit firms. 
Dr. Hebatallah Badawy

\subsection{Models specifications}

To test the effect of current year qualified audit opinion on next year audit fees, the following OLS regression model is developed:

\section{Model 1:}

$$
\begin{gathered}
\text { LN }\left(A U D I T_{-} F E E S_{i t+1}\right)=\beta_{0}+\beta_{1} \text { AUDIT_OPINION }{ }_{i t}+\beta_{2} \text { SIZE }_{i t}+ \\
\beta_{3} A G E_{i t}+\beta_{4} P R O F I T_{i t}+\beta_{5} \text { COMPLEXITY } \\
i t
\end{gathered}
$$

To test the interaction effect of current year qualified audit opinion and family ownership on next year audit fees, the following OLS regression model is developed:

\section{Model 2:}

$$
\begin{aligned}
& \text { LN }\left(A U D I T \_F E E S_{i t+1}\right)=\beta_{0}+\beta_{1} A U D I T \_O P I N I O N_{i t}+\beta_{2} F_{-} A M I L Y_{i t}+ \\
& \beta_{3} A U D I T \_O P I N I O N^{*} F A M I L Y_{i t}+\beta_{4} S_{Z} E_{i t}+\beta_{5} A G E_{i t}+\beta_{6} P_{R O F I T}+ \\
& \text { 4. Empirical Findings } \\
& \beta_{7} C O M P L E X I T Y_{i t}+\beta_{9} B U S Y_{i t}+\varepsilon_{i t}
\end{aligned}
$$

\subsection{Descriptive statistics}

Table (3) presents the descriptive statistics of the independent, dependent and control variables. It is obvious from the descriptive statistics that the natural logarithm of audit fees ranges from 9.5468 to 13.7642 with an average 11.4539 and standard deviation 0.8868 . As shown in table (3), $19.83 \%$ of the firms in the sample receive qualified audit opinion with a standard deviation 0.3993 . It is also clear that $28 \%$ of the firms in the sample are family firms. Size of firms in the sample ranges from 15.79 to 25.29 with standard deviation 1.90. Most of the firms (82\%) achieved profits. Average firms' complexity is 33\% with standard deviation $0.2296 .92 \%$ of the firms issue their financial statements in the busy season. 
Dr. Hebatallah Badawy

Table (3) Descriptive statistics

\begin{tabular}{|l|c|c|c|c|c|c|c|}
\hline & $\begin{array}{c}\text { Expected } \\
\text { Sign }\end{array}$ & Mean & Median & Min & Max & SD & N \\
\hline LN(AUDIT_FEES) & & 11.4539 & 11.4076 & 9.5468 & 13.7642 & 0.8869 & 358 \\
\hline AUDIT_OPINION & + & 0.1983 & 0.0000 & 0.0000 & 1.0000 & 0.3993 & 358 \\
\hline FAMILY & - & 0.2800 & 0.0000 & 0.0000 & 1.0000 & 0.4490 & 358 \\
\hline SIZE & + & 20.4662 & 20.4314 & 15.7935 & 25.2905 & 1.9043 & 358 \\
\hline AGE & + & 3.3102 & 3.4012 & 0.0000 & 4.7095 & 0.5881 & 358 \\
\hline PROFIT & $+/-$ & 0.8200 & 1.0000 & 0.0000 & 1.0000 & 0.3860 & 358 \\
\hline COMPLEXITY & + & 0.3301 & 0.2886 & 0.0000 & 0.9905 & 0.2296 & 358 \\
\hline BUSY & + & 0.9200 & 1.0000 & 0.0000 & 1.0000 & 0.2770 & 358 \\
\hline
\end{tabular}

\subsection{Correlation analysis}

From table (4), the author can initially conclude that current year qualified audit opinion is positively associated with next year audit fees. As for family ownership, it is clear that it is negatively and significantly associated with next year audit fees. Concerning the control variables, the author can conclude that firm size, age, profitability and busy season are positively associated with next year audit fees. On the other side, complexity is negatively but insignificantly associated with audit fees. As for the correlation between the independent and control variables, it is clear that the maximum correlation is $43 \%$ and from the VIF factors shown in the next section, the author can conclude that there is no multicollinearity problem that might affect the regression results. 


\section{Dr. Hebatallah Badawy}

Table (4): Correlation analysis

\begin{tabular}{|l|c|c|c|c|c|c|c|c|}
\hline & $\begin{array}{c}\text { LN(AUDI } \\
T F E E S)\end{array}$ & $\begin{array}{c}\text { AUDIT_O } \\
P I N I O N\end{array}$ & FAMILY & SIZE & AGE & PROFIT & $\begin{array}{c}\text { COMPL } \\
\text { EXITY }\end{array}$ & BUSY \\
\hline $\begin{array}{l}\text { LN(AUDIT_FE } \\
\text { ES) }\end{array}$ & 1.00 & & & & & & & \\
\hline $\begin{array}{l}\text { AUDIT_OPINI } \\
\text { ON }\end{array}$ & $0.118^{* *}$ & 1 & & & & & & \\
\hline $\boldsymbol{F A M I L Y}$ & $-0.242^{* * *}$ & -0.044 & 1 & & & & & \\
\hline SIZE & $0.733^{* * *}$ & $-0.106^{*}$ & -0.031 & 1 & & & & \\
\hline $\boldsymbol{A G E}$ & $0.173^{* * *}$ & $0.093^{*}$ & $-0.268^{* * *}$ & -0.006 & 1 & & & \\
\hline $\boldsymbol{P R O F I T}$ & $0.130^{* *}$ & $-0.093^{*}$ & $0.099^{*}$ & $0.162^{* * *}$ & -0.061 & 1 & & \\
\hline COMPLEXITY & -0.057 & -0.040 & $0.130^{* *}$ & $-0.185^{* * *}$ & $-0.132^{* *}$ & $0.106^{* *}$ & 1 & \\
\hline BUSY & $0.090^{*}$ & $-0.431^{* * *}$ & 0.076 & 0.020 & $-0.196^{* * *}$ & 0.014 & 0.050 & 1 \\
\hline
\end{tabular}

significant at 0.10 level

\subsection{Hypotheses testing}

Table (5) presents the regression results of the base model (Model1). First, the adjusted $\mathrm{R}^{2}$ of the regression model is $58.6 \%$, which is consistent with prior studies in this area (e.g. Cahan and Sun, 2015). Second, the VIF of all variables in the model are less than 10, which means that multicollinearity is not a problem that may affect the regression results. Third, Durbin Watson statistic, which is a measure of autocorrelation indicates no significant autocorrelation.

To test the first research hypothesis (H1), the regression results in table (5) show that AUDIT_OPINION is negatively but insignificantly associated with next year audit fees (Sig. $=0.867)$. This result, which is consistent with that of Shan et al. (2019), implies that current year qualified audit opinion will have no significant effect on the auditor's decision with regards to audit pricing. This result might be justified that auditors who issue qualified audit opinion for a firm have already exerted more efforts during their last year audit and have included all their comments and qualifications in their audit report. This exerted effort might save efforts for the next year audit. Accordingly, the first research hypothesis (H1) is not supported. 


\section{Dr. Hebatallah Badawy}

Among the control variables, regression results show that SIZE is positively associated with audit fees at the $1 \%$ level of significance, suggesting that large firms require more audit time and efforts and that's why auditors may charge those firms higher audit fees. This result is consistent with Joshi and Al-Bastaki (2000) and Smith et al. (2019). Also, consistent with Barua, et al. (2019) and Smith et al. (2019), COMPLEXITY is positively associated with audit fees, implying that the risks related to such accounts will require auditors to make special auditing procedures such as confirmation, and this will make auditors ask for a fee premium.

Consistent with Barua et al. (2019) and Bhattacharya and Banerjee (2020), regression results show that $A G E$ is positively associated with audit fees at the $1 \%$ significance level, suggesting that as firms become older and more involved in transactions, they will need more efforts and sometimes require higher experience level. This will put pressure on auditors to incur higher costs and so will ask for higher audit fees. In addition, the author believes that as time passes and the general price level increases, auditors will incur higher costs and ask for higher salaries and so will charge their clients higher audit fees.

Concerning the impact of PROFIT on next year audit fees, regression results show positive but insignificant association between both variables. This result is inconsistent with prior research that found positive and significant association between both variables. An interpretation for this result might be due to different profitability measures, as for instance, Joshi and Al-Bastaki, 2000 used ROA to measure profitability.

Finally, unlike prior research results of Joshi and Al-Bastaki, 2000, but as expected and consistent with Ng et al. (2018), Zhang (2018) and Kharuddin et al., (2019), firms that have their fiscal year end in December, during the busy season, require overtime audit work and auditors will be under pressure in order to issue their audit report within the required time. Accordingly, the regression result shows that BUSY is positively associated with audit fees at the $1 \%$ level of significance. 
Dr. Hebatallah Badawy

\begin{tabular}{|c|c|c|c|c|}
\hline \multicolumn{5}{|c|}{ Table (5) Regression Results: Audit opinion and audit fees } \\
\hline & \multicolumn{4}{|c|}{ Model 1} \\
\hline & & \multicolumn{2}{|c|}{$\begin{array}{l}\text { Standardized } \\
\text { coefficients }\end{array}$} & \multirow[b]{2}{*}{ Sig. } \\
\hline Variables & VIF & $\boldsymbol{\beta}$ & $\mathbf{t}$ & \\
\hline (Constant) & & & 6.557 & 0.000 \\
\hline AUDIT_OPINION & 1.252 & -0.006 & -0.168 & 0.867 \\
\hline SIZE & 1.085 & 0.750 & 21.129 & $0.000^{* * *}$ \\
\hline$A G E$ & 1.059 & 0.214 & 6.098 & $0.000^{* * *}$ \\
\hline PROFIT & 1.056 & 0.008 & 0.225 & 0.822 \\
\hline COMPLEXITY & 1.076 & 0.104 & 2.943 & $0.003^{* * *}$ \\
\hline BUSY & 1.269 & 0.109 & 2.827 & $0.005^{* * *}$ \\
\hline \multicolumn{2}{|l|}{$\mathrm{R}^{2}$} & 0.593 & & \\
\hline \multicolumn{2}{|l|}{ Adj. $\mathrm{R}^{2}$} & 0.586 & & \\
\hline \multicolumn{2}{|l|}{ Std. error } & 0.57095 & & \\
\hline \multicolumn{2}{|l|}{ Durbin-Watson } & 1.631 & & \\
\hline \multicolumn{2}{|l|}{ F value } & 85.061 & & \\
\hline \multicolumn{2}{|l|}{ Sig. F } & $0.000^{* * *}$ & & \\
\hline \multicolumn{2}{|l|}{$\mathrm{N}$} & 358 & & \\
\hline
\end{tabular}

$* * *=$ significant at 0.01 level, $* *=$ significant at 0.05 level, $*=$

significant at 0.10 level

To test the second research hypothesis (H2), family ownership FAMILY variable and a moderating variable AUDIT_OPINION*FAMILY showing the interaction between qualified audit opinion and family ownership have been added to the base model. Table (6) presents the results of the interaction of current year qualified audit opinion and family ownership. First, the Adj. $\mathrm{R}^{2}$ showed improvement from $58.6 \%$ to $63.1 \%$. Second, the VIF column shows that there is no multicollinearity problem, and the Durbin-Watson statistic shows no autocorrelation problem. 


\section{Dr. Hebatallah Badawy}

It is clear from table (6) that AUDIT_OPINION is negatively associated with next year audit fees at $10 \%$ significant level $($ Sig. $=0.091)$. This result indicates that auditors who issue qualified audit opinion for the current year will not ask for a fee premium for auditing the next year financial statements. Also, consistent with Khan et al. (2011) and Ben Ali and Lesage (2014), regression results indicate that FAMILY has a significant negative effect on audit fee determinacy (Sig. $=0.000)$, which is consistent with the alignment effect hypothesis and the low information asymmetry between managers and shareholders hypothesis.

On the other side, AUDIT_OPINION*FAMILY has a significant positive effect on next year audit fees $(\mathrm{Sig} .=0.004)$. This result might show that, consistent with the entrenchment effect hypothesis, family members might work for their interest on the expense of minority interest and this might result in higher agency problems. When auditors discover financial problems and issue a qualified audit opinion, they will assess audit risk at a higher level and will ask for higher audit fees for the future audit missions. Accordingly, the second research hypothesis (H2) is supported.

Consistent with the regression results of Model (1) shown in table (5), the control variables; SIZE (Sig. = 0.000), AGE (Sig. 0.000), COMPLEXITY (Sig. $=0.002)$ and BUSY $($ Sig. $=0.014)$ are positively and significantly associated with next year audit fees. However, PROFIT is positively but insignificantly associated with next year audit fees (Sig. = 0.353). 
Dr. Hebatallah Badawy

\begin{tabular}{|c|c|c|c|c|}
\hline \multicolumn{5}{|c|}{$\begin{array}{l}\text { Table (6) Regression Results: The interaction effect of family } \\
\text { ownership and current year audit opinion on next year audit fees }\end{array}$} \\
\hline & \multicolumn{4}{|c|}{ Model 2} \\
\hline & & \multicolumn{2}{|c|}{$\begin{array}{c}\text { Standardized } \\
\text { coefficients }\end{array}$} & \multirow[b]{2}{*}{ Sig. } \\
\hline Variables & VIF & $\beta$ & $\mathbf{t}$ & \\
\hline (Constant) & & & 7.927 & 0.000 \\
\hline AUDIT_OPINION & 1.717 & -0.072 & -1.697 & $0.091^{*}$ \\
\hline FAMILY & 1.322 & -0.247 & -6.685 & $0.000^{* * *}$ \\
\hline AUDIT_OPINION ${ }^{*} F A M I L Y$ & 1.638 & 0.120 & 2.925 & $0.004^{* * *}$ \\
\hline SIZE & 1.088 & 0.749 & 22.301 & $0.000^{* * *}$ \\
\hline$A G E$ & 1.130 & 0.158 & 4.619 & $0.000^{* * *}$ \\
\hline PROFIT & 1.068 & 0.031 & 0.929 & 0.353 \\
\hline COMPLEXITY & 1.102 & 0.108 & 3.191 & $0.002^{* * *}$ \\
\hline BUSY & 1.322 & 0.091 & 2.462 & $0.014^{* *}$ \\
\hline \multicolumn{2}{|l|}{$\mathrm{R}^{2}$} & 0.639 & & \\
\hline \multicolumn{2}{|l|}{ Adj. $\mathrm{R}^{2}$} & 0.631 & & \\
\hline \multicolumn{2}{|l|}{ Std. error } & 0.5391 & & \\
\hline \multicolumn{2}{|l|}{ Durbin-Watson } & 1.817 & & \\
\hline \multicolumn{2}{|l|}{ F value } & 77.150 & & \\
\hline \multicolumn{2}{|l|}{ Sig. F } & $0.000^{* * *}$ & & \\
\hline \multicolumn{2}{|l|}{$\mathrm{N}$} & 358 & & \\
\hline
\end{tabular}

$* * *=$ significant at 0.01 level, $* *=$ significant at 0.05 level, $*=$ significant at 0.10 level

\subsection{Sensitivity analyses}

To test the robustness of the main empirical results, several analyses were conducted. First, three alternative measures for audit fees and an alternative measure for audit opinion are being used. Second the total sample is divided according to family ownership variable and the effect of audit opinion on audit fees is examined on each subsample (family vs non-family firms). 


\section{Dr. Hebatallah Badawy}

\subsubsection{Alternative measures of audit fees}

The first alternative measure is the total value of audit fees (in Egyptian pounds) following Ben Ali and Lesage (2014). Based on this alternative measure, the following OLS regression model is developed:

\section{Model 3:}

TOTAL_AUDIT_FEES it $+1=\beta_{0}+\beta_{1}$ AUDIT_OPINION ${ }_{i t}+\beta_{2}$ FAMILY $_{i t}+$ $\beta_{3} A U D I T \_O P I N I O N^{*} F A M I L Y_{i t}+\beta_{4} S_{I Z E_{i t}^{-}}+\beta_{5} A G E_{i t}+\beta_{6} P R O F I T_{i t}+$

$$
\beta_{7} \text { COMPLEXITY }{ }_{i t}+\beta_{8} B U S Y_{i t}+\varepsilon_{i t}
$$

Consistent with Dhaliwal et al. (2008), the second alternative measure of audit fees is total fees divided by square root of total assets. Based on this alternative measure, the following OLS regression model is developed:

\section{Model 4:}

$$
\begin{aligned}
& \text { AUDIT_FEES } S_{i t+1} / S Q R \_T O T A L \_A S S E T S=\beta_{0}+\beta_{1} A U D I T \_O P I N I O N_{i t}+ \\
& \beta_{2} F A \overline{M I L Y} Y_{i t}+\beta_{3} A U D \overline{I T} \text { OPINION*FAMILY } Y_{i t}+\beta_{4} S_{S I Z E_{i t}}+\beta_{5} A G E_{i t}+ \\
& \beta_{6} P_{R O F I T_{i t}}+\beta_{7} C O M P L E X I T Y_{i t}+\beta_{8} B U S Y_{i t}+\varepsilon_{i t}
\end{aligned}
$$

The third alternative measure of audit fees is total fees divided by total assets, following Foster and Shastri (2016). Based on this alternative measure, the following OLS regression model is developed:

\section{Model 5:}

AUDIT_FEES it $+1_{1}$ TOTAL_ASSETS $=\beta_{0}+\beta_{1}$ AUDIT_OPINION ${ }_{i t}+$ $\beta_{2}$ FAMILY ${ }_{i t}+\beta_{3}$ AUDIT_OPINION ${ }^{*} F A M I L Y_{i t}+\beta_{4} S I \bar{Z} E_{i t}+\beta_{5} A G E_{i t}+$ $\beta_{6} P_{R O F I T_{i t}}+\beta_{7} C O M P L E X I T Y_{i t}+\beta_{8} B U S Y_{i t}+\varepsilon_{i t}$

Table (7) shows the regression results after using the three alternative measures of audit fees, where audit fees are measured by total value of audit fees in Model (3), total fees divided by square root of total fees in Model (4) and total fees divided by total assets in Model (5).

Consistent with Harjoto et al. (2015), the results in table (7) are weaker because of the skewness of the variable, measured by the value of audit fees. It is obvious that AUDIT_OPINION is negatively and significantly associated with next year audit fees in Model (3) only (Sig. = 0.016). However, AUDIT_OPINION turned to be negatively but insignificantly associated with the next year audit fees in Model (4) (Sig. $=0.127)$ and Model (5) (Sig. $=0.411)$. This result indicates that auditors who issue qualified audit opinion for the current year will not ask for a fee premium for auditing the next year financial statements. 


\section{Dr. Hebatallah Badawy}

Consistent with the main results shown in table (6), FAMILY is negatively and significantly associated with next year audit fees in Model (3) $($ Sig. $=0.000), \operatorname{Model}(4)($ Sig. $=0.000)$ and Model (5) $($ Sig. $=0.003)$.

Additionally, AUDIT_OPINION*FAMILY is positively and significantly associated with next year audit fees in Model (3) (Sig. = 0.023 ), Model (4) (Sig. $=0.0013)$ and Model (5) (Sig. $=0.000)$. This indicates that the results of the study concerning the second research hypothesis (H2) are robust to the three alternative measures of audit fees.

Concerning the control variables, SIZE is positively and significantly associated with next year audit fees in Model (3) (Sig. = 0.000), however, it turned to be negative and significant in Model (4) (Sig. $=0.000)$ and Model (5) (Sig. $=0.000)$. This result might be due to using alternative measures of audit fees that rely on the firm's assets to be calculated. $A G E$ is positively and significantly associated with next year audit fees in Model (3) (Sig. $=0.049$ ) and Model (4) (Sig. =0.0045). However, in model (5), it turned to be negatively and significantly associated with next year audit fees (Sig. $=0.000)$.

Concerning PROFIT, it is positively but insignificantly associated with next year audit fees in Model (3) (Sig. $=0.287)$, but this relationship turned to be positive and significant in Model (4) (Sig. $=0.094)$ at $10 \%$ significance level and Model (5) (Sig. $=0.008)$. This result is consistent with the study of Joshi and Al-Bastaki (2000), which found that profitable firms might require more audit effort and stricter audit investigations to test the validity of the expenses and revenues recognition. COMPLEXITY is positively but insignificantly associated with next year audit fees in Model (3) $($ Sig. $=0.128)$, Model (4) $($ Sig. $=0.102)$ and Model (5) $($ Sig. $=$ 0.906).

Finally, $B U S Y$ is positively and significantly associated with next year audit fees in models $(3)($ Sig. $=0.080)$ and $(4)($ Sig. $=0.022)$, implying that firms that have financial year end on December $31^{\text {st }}$ require a lot of effort and more audit work and so higher audit fees will be requested by their auditors. On the other side, and consistent with Firth (2002) and Ben Ali and Lesage (2014), BUSY is insignificantly associated with audit fees in model (5) $($ Sig. $=0.105)$. 
Scientific Journal for Financial and Commercial Studies and Researches

Dr. Hebatallah Badawy

Table (7) Regression results: Alternative measures of next year audit fees

\begin{tabular}{|c|c|c|c|c|c|c|c|c|c|}
\hline \multirow[b]{2}{*}{ Variables } & \multicolumn{3}{|c|}{ Model 3} & \multicolumn{3}{|c|}{ Model 4} & \multicolumn{3}{|c|}{ Model 5} \\
\hline & $\boldsymbol{\beta}$ & $\mathbf{t}$ & Sig. & $\beta$ & $\mathbf{t}$ & Sig. & $\beta$ & $\mathbf{t}$ & Sig. \\
\hline (Constant) & & -8.903 & 0.000 & & 4.111 & 0.000 & & 16.264 & 0.000 \\
\hline $\begin{array}{l}\text { AUDIT_OPINI } \\
\text { ON }\end{array}$ & -0.137 & -2.429 & $0.016^{* *}$ & -0.098 & -1.531 & 0.127 & -0.040 & -0.823 & 0.411 \\
\hline FAMILY & -0.256 & -5.190 & $0.000^{* * *}$ & -0.274 & -4.883 & $0.000^{* * *}$ & -0.125 & -2.951 & $0.003^{* * *}$ \\
\hline $\begin{array}{l}\text { AUDIT_OPINI } \\
\text { ON*FAMILY }\end{array}$ & 0.250 & 2.291 & $0.023^{* *}$ & 0.156 & 2.489 & $0.013^{* *}$ & 0.211 & 4.470 & $0.000^{* * *}$ \\
\hline SIZE & 0.517 & 11.552 & $0.000^{* * *}$ & -0.244 & -4.791 & $0.000^{* * *}$ & -0.651 & -16.886 & $0.000^{* * *}$ \\
\hline$A G E$ & 0.090 & 1.978 & $0.049^{* *}$ & 0.104 & 2.014 & $0.045^{* *}$ & -0.226 & -5.743 & $0.000^{* * *}$ \\
\hline PROFIT & 0.047 & 1.067 & 0.287 & 0.085 & 1.678 & $0.094^{*}$ & 0.102 & 2.672 & $0.008^{* * *}$ \\
\hline COMPLEXITY & 0.069 & 1.528 & 0.128 & 0.084 & 1.640 & 0.102 & 0.005 & 0.119 & 0.906 \\
\hline BUSY & 0.087 & 1.757 & $0.080^{*}$ & 0.129 & 2.295 & $0.022^{* *}$ & 0.069 & 1.625 & 0.105 \\
\hline $\mathrm{R}^{2}$ & & 0.358 & & & 0.169 & & & 0.524 & \\
\hline Adj. $\mathrm{R}^{2}$ & & 0.343 & & & 0.150 & & & 0.513 & \\
\hline Std. error & & 124527.7 & & & 2.8772 & & & 0.00028 & \\
\hline Durbin-Watson & & 1.655 & & & 1.873 & & & 1.992 & \\
\hline F value & & 24.303 & & & 8.845 & & & 47.981 & \\
\hline Sig. F & & $0.000^{* * *}$ & & & $0.000^{* * *}$ & & & $0.000^{* * *}$ & \\
\hline $\mathrm{N}$ & & 358 & & & 358 & & & 358 & \\
\hline
\end{tabular}

$* * *=$ significant at 0.01 level, $* *=$ significant at 0.05 level, $*=$ significant at 0.10 level

\subsubsection{Alternative measure of current year audit opinion}

In this section, the author used a detailed measure for audit opinion through including two dummy variables, EMPHASIS_OPINION if the current year audit opinion is clean with a matter of emphasis (explanatory) paragraph and QUALIFIED_OPINION if the audit opinion is qualified (Tahinakis and Samarinas, 2016). Based on this alternative measure, the following OLS regression model is developed: 
Dr. Hebatallah Badawy

Model 6:

$$
\begin{aligned}
& \text { LN }\left(A U D I T \_F E E S_{i t+1}\right)=\beta_{0}+\beta_{1} \text { EMPHASIS_OPINION }{ }_{i t}+ \\
& \beta_{2} Q U \text { ULIFIED_OPINION }{ }_{i t}+\beta_{3} F A M I L Y_{i t}+ \\
& \beta_{4} \text { EMPHASIS_OPINION*FAMILY } Y_{i t}+ \\
& \beta_{5} Q U A L I F I E D \_O P I N I O N^{*} F A M I L Y_{i t}+\beta_{6} S I Z E_{i t}+\beta_{7} A G E_{i t}+\beta_{8} P R O F I T_{i t} \\
& +\beta_{9} C O M P L E X I T Y_{i t}+\beta_{10} B U S Y_{i t}+\varepsilon_{i t}
\end{aligned}
$$

Table (8) shows that the effect of current year audit opinion on next year audit fees is not significant. It is clear that QUALIFIED_OPINION is negatively but insignificantly associated with next year audit fees (Sig. = 0.124), however EMPHASIS_OPINION is positively but also insignificantly associated with next year audit fees (Sig. $=0.690)$. This result is consistent with Bedard et al. (2019) that found that expanded audit reports which include justification of assessment or critical audit matters or key audit matters doesn't have a significant effect on audit fees.

Consistent with the regression results shown in tables (6) and (7), FAMILY is negatively and significantly associated with next year audit fees $($ Sig. $=0.000)$ and QUALIFIED_OPINION*FAMILY has a significant positive impact on next year audit fees, indicating that auditors ask for a higher fee premium if the firm is defined as a family firm and the auditor issued a qualified audit opinion (Sig. $=0.007$ ). However, EMPHASIS_OPINION*FAMILY has an insignificant negative effect, indicating that auditors will not ask for a fee premium (Sig. $=0.767)$.

Regarding the effect of control variable, table (8) reveals that SIZE $($ Sig. $=0.000), A G E($ Sig. $=0.000), C O M P L E X I T Y($ Sig. $=0.001)$ and $B U S Y$ (Sig. $=0.016$ ) have a significant positive impact on next year audit fees. On the other side, PROFIT is positively but insignificantly associated with next year audit fees (Sig. $=0.340)$. 
Dr. Hebatallah Badawy

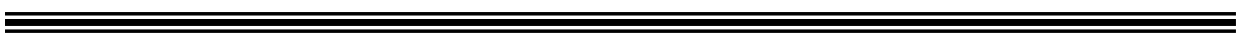

Table (8) Regression results: Alternative measure of current year audit opinion

\begin{tabular}{|c|c|c|c|c|}
\hline \multirow[b]{3}{*}{ Variables } & \multicolumn{4}{|c|}{ Model 6} \\
\hline & \multirow[b]{2}{*}{ VIF } & \multicolumn{2}{|c|}{$\begin{array}{c}\text { Standardized } \\
\text { coefficients }\end{array}$} & \multirow[b]{2}{*}{ Sig. } \\
\hline & & $\beta$ & $\mathbf{t}$ & \\
\hline (Constant) & & & 7.890 & 0.000 \\
\hline EMPHASIS_OPINION & 1.641 & 0.016 & 0.399 & 0.690 \\
\hline QUALIFIED_OPINION & 1.833 & -0.067 & -1.543 & 0.124 \\
\hline FAMILY & 1.935 & -0.241 & -5.367 & $0.000^{* * *}$ \\
\hline EMPHASIS_OPINION*FAMILY & 2.205 & -0.014 & -0.297 & 0.767 \\
\hline QUALIFIED_OPINION*FAMILY & 1.764 & 0.117 & 2.736 & $0.007^{* * *}$ \\
\hline$S I Z E$ & 1.113 & 0.748 & 21.984 & $0.000^{* * *}$ \\
\hline$A G E$ & 1.141 & 0.157 & 4.566 & $0.000^{* * *}$ \\
\hline PROFIT & 1.076 & 0.032 & 0.956 & 0.340 \\
\hline COMPLEXITY & 1.105 & 0.109 & 3.200 & $0.001^{* * *}$ \\
\hline BUSY & 1.338 & 0.091 & 2.429 & $0.016^{* *}$ \\
\hline \multicolumn{2}{|l|}{$\mathrm{R}^{2}$} & 0.639 & & \\
\hline \multicolumn{2}{|l|}{ Adj. $\mathrm{R}^{2}$} & 0.629 & & \\
\hline \multicolumn{2}{|l|}{ Std. error } & 0.5405 & & \\
\hline \multicolumn{2}{|l|}{ Durbin-Watson } & 1.821 & & \\
\hline \multicolumn{2}{|l|}{ F value } & 61.412 & & \\
\hline \multicolumn{2}{|l|}{ Sig. F } & 0.000 & & \\
\hline \multicolumn{2}{|l|}{$\mathrm{N}$} & 358 & & \\
\hline
\end{tabular}

$* * *=$ significant at 0.01 level, $* *=$ significant at 0.05 level, $*=$ significant at 0.10 level

\subsubsection{Family vs Non-Family}

The sample is divided according to family ownership into two subsamples, the first one includes 258 observations (non-family firms) and the second one includes 100 observations (family firms). The OLS regression model (Model 1) will be run on each sample separately. 


\section{Dr. Hebatallah Badawy}

To test the differences in mean, two tailed t-test was used. From table (9), it is clear that there is significant difference between audit fees of family firms and that of non-family firms. Audit fees are higher in nonfamily firms in comparison with family firms. This result confirmed the author's prior justification and results that showed that family firms don't suffer from higher agency costs and according to the alignment effect hypothesis, family members will monitor their firms and will do their best to pass a successful business to the future generations. Accordingly, family firms will not seek higher quality audits and will be less reluctant to demand Big4 audit services. Also, it is obvious that there are significant differences between the two subsamples with regard to firm age, profitability and complexity.

Table (9) Differences in means between family and non-family samples

\begin{tabular}{|l|c|c|c|c|c|}
\hline & \multicolumn{2}{|c|}{ Non-family } & \multicolumn{2}{c|}{ Family } & \\
\hline & Mean & $\begin{array}{c}\text { Std. } \\
\text { Dev. }\end{array}$ & Mean & $\begin{array}{c}\text { Std. } \\
\text { Dev. }\end{array}$ & $\begin{array}{c}\text { Differences in } \\
\text { Mean }\end{array}$ \\
\hline LNAUDIT FEES & 11.5875 & 0.8953 & 11.1092 & 0.7675 & $0.4783^{* * *}$ \\
\hline AUDIT_OPINION & 0.2093 & 0.4076 & 0.17 & 0.3775 & 0.0393 \\
\hline SIZE & 20.5026 & 1.6716 & 20.3723 & 2.4104 & 0.1303 \\
\hline AGE & 3.4082 & 0.5714 & 3.0574 & 0.5569 & $0.3508^{* * *}$ \\
\hline PROFIT & 0.79 & 0.405 & 0.88 & 0.327 & $-0.09^{*}$ \\
\hline COMPLEXITY & 0.3116 & 0.2170 & 0.3779 & 0.2545 & $-0.0664^{* *}$ \\
\hline BUSY & 0.90 & 0.296 & 0.95 & 0.219 & -0.05 \\
\hline
\end{tabular}

$* * *=$ significant at 0.01 level, $* *=$ significant at 0.05 level, $*=$ significant at 0.10 level It is clear from table (10) that for non-family firms, AUDIT_OPINION is negatively but insignificantly associated with next year audit fees $(\mathrm{Sig} .=0.275)$. The most significant determinants of audit fees are SIZE (Sig. $=0.000), A G E($ Sig. $=0.008)$ and $B U S Y($ Sig. $=0.005)$. On the other side, PROFIT (Sig. $=0.719$ ) and COMPLEXITY (Sig. = 0.153 ) are positively but insignificantly associated with next year audit fees. 


\section{Dr. Hebatallah Badawy}

However, for family firms, AUDIT_OPINION is positively but insignificantly associated with next year audit fees (Sig. $=0.152)$. This result is consistent with that of Firth (2002) and Kharuddin et al. (2019). Analogous to the results of non-family firms, regression results in table (11) provide evidence that SIZE (Sig. $=0.000)$ and $A G E($ Sig. $=0.000)$ are positively and significantly associated with next year audit fees. However, family firms are different from non-family firms in the impact of complexity and busy season, as COMPLEXITY was shown to be positively and significantly associated with next year audit fees $($ Sig. $=0.000)$ and $B U S Y$ is negatively and insignificantly associated with next year audit fees (Sig. = 0.591). Also, consistent with non-family firms, PROFIT is positively and insignificantly associated with next year audit fees (Sig. = 0.874).

Table (10) Regression results: family vs non-family

\begin{tabular}{|c|c|c|c|c|c|c|c|c|}
\hline \multirow[b]{2}{*}{ Variables } & \multicolumn{4}{|c|}{ Non-Family } & \multicolumn{4}{|c|}{ Family } \\
\hline & VIF & $\beta$ & $\mathbf{t}$ & Sig. & VIF & $\beta$ & $\mathbf{t}$ & Sig. \\
\hline (Constant) & & & 4.206 & 0.000 & & & 8.291 & 0.000 \\
\hline $\begin{array}{l}\text { AUDIT_OPINI } \\
\text { ON }\end{array}$ & 1.376 & -0.050 & -1.093 & 0.275 & 1.176 & 0.080 & 1.443 & 0.152 \\
\hline SIZE & 1.084 & 0.760 & 18.679 & $0.000^{* * *}$ & 1.119 & 0.890 & 16.534 & $0.000^{* * *}$ \\
\hline$A G E$ & 1.071 & 0.108 & 2.681 & $0.008^{* * *}$ & 1.055 & 0.238 & 4.553 & $0.000^{* * *}$ \\
\hline PROFIT & 1.039 & 0.014 & 0.360 & 0.719 & 1.305 & 0.009 & 0.160 & 0.874 \\
\hline COMPLEXITY & 1.078 & 0.058 & 1.432 & 0.153 & 1.266 & 0.261 & 4.564 & $0.000^{* * *}$ \\
\hline BUSY & 1.401 & 0.131 & 2.844 & $0.005^{* * *}$ & 1.031 & -0.028 & -0.539 & 0.591 \\
\hline \multicolumn{2}{|l|}{$\mathrm{R}^{2}$} & 0.617 & & & & & 0.759 & \\
\hline \multicolumn{2}{|c|}{ Adj. $\mathrm{R}^{2}$} & 0.608 & & & & & 0.744 & \\
\hline \multicolumn{2}{|c|}{ Std. error } & 0.5606 & & & & & 0.3887 & \\
\hline \multicolumn{2}{|c|}{ Durbin-Watson } & 1.911 & & & & & 1.600 & \\
\hline \multicolumn{2}{|c|}{ F value } & 67.414 & & & & & 48.832 & \\
\hline \multicolumn{2}{|c|}{ Sig. F } & $0.000^{* * *}$ & & & & & $0.000^{* * *}$ & \\
\hline \multicolumn{2}{|l|}{$\mathrm{N}$} & 258 & & & & & 100 & \\
\hline
\end{tabular}

$* * *=$ significant at 0.01 level, $* *=$ significant at 0.05 level, $*=$ significant at 0.10 level. 


\subsection{Additional analysis}

In this section, an audit related control variable, audit quality (AUDIT_QUALITY) is added to the OLS regression model to show its impact on next year audit fees. Accordingly, the following OLS regression model is developed:

\section{Model 7:}

$$
\begin{aligned}
& \text { LN(AUDIT_FEES } \left.S_{i t+1}\right)=\beta_{0}+\beta_{1} \text { AUDIT_OPINION }{ }_{i t}+\beta_{2} \text { FAMILY }_{i t}+ \\
& \beta_{3} A U D I T \_O P I N I O N^{*} F A M I L Y_{i t}+\beta_{4} S I Z E_{i t}+\beta_{5} A G E_{i t}+\beta_{6} P R O F I T_{i t}+ \\
& \beta_{7} C_{C O M P L E X I T Y}+\beta_{8} B U S Y_{i t}+\beta_{9} A U D I T \_Q U A L I T Y_{i t}+\varepsilon_{i t}
\end{aligned}
$$

Consistent with Ben Ali and Lesage (2014) and Jacob et al. (2019), AUDIT_QUALITY has a significant positive impact on next year audit fees $($ Sig. $=0.000)($ table 11). This result suggests that Big4 audit firms charge their clients fee premiums because of their reputation, experience and superior audit quality. Again, FAMILY has a significant negative impact on next year audit fees $($ Sig. $=0.000)$ and AUDIT_OPINION*FAMILY is positively and significantly associated with next year audit fees (Sig. = 0.002). SIZE (Sig. =0.000), AGE (Sig. $=0.000)$ and COMPLEXITY (Sig. $=0.005)$ are positively and significantly associated with next year audit fees. On the other side, PROFIT (Sig. $=0.201)$ and BUSY $($ Sig. $=0.125)$ were proven to be positively but insignificantly associated with next year audit fees. 
Dr. Hebatallah Badawy

\begin{tabular}{|c|c|c|c|c|}
\hline \multicolumn{5}{|c|}{ Table (11) Regression results: Additional analysis } \\
\hline & \multicolumn{4}{|c|}{ Model 7} \\
\hline & & \multicolumn{2}{|c|}{$\begin{array}{c}\text { Standardized } \\
\text { coefficients }\end{array}$} & \\
\hline Variables & VIF & $\boldsymbol{\beta}$ & $\mathbf{t}$ & Sig. \\
\hline (Constant) & & & 10.002 & 0.000 \\
\hline AUDIT_OPINION & 1.739 & -0.045 & -1.104 & 0.270 \\
\hline FAMILY & 1.340 & -0.223 & -6.280 & $0.000^{* * *}$ \\
\hline AUDIT_OPINION*FAMILY & 1.638 & 0.120 & 3.047 & $0.002^{* * *}$ \\
\hline SIZE & 1.361 & 0.653 & 18.232 & $0.000^{* * *}$ \\
\hline$A G E$ & 1.148 & 0.133 & 4.057 & $0.000^{* * *}$ \\
\hline PROFIT & 1.071 & 0.041 & 1.281 & 0.201 \\
\hline COMPLEXITY & 1.111 & 0.090 & 2.796 & $0.005^{* * *}$ \\
\hline BUSY & 1.361 & 0.055 & 1.540 & 0.125 \\
\hline AUDIT_QUALITY & 1.385 & 0.216 & 5.988 & $0.000^{* * *}$ \\
\hline \multicolumn{2}{|l|}{$\mathrm{R}^{2}$} & 0.673 & & \\
\hline \multicolumn{2}{|l|}{ Adj. $\mathrm{R}^{2}$} & 0.664 & & \\
\hline \multicolumn{2}{|l|}{ Std. error } & 0.5140 & & \\
\hline \multicolumn{2}{|l|}{ Durbin-Watson } & 1.827 & & \\
\hline \multicolumn{2}{|l|}{ F value } & 79.410 & & \\
\hline \multicolumn{2}{|l|}{ Sig. F } & $0.000^{* * *}$ & & \\
\hline \multicolumn{2}{|l|}{$\mathrm{N}$} & 358 & & \\
\hline
\end{tabular}

$* * *=$ significant at 0.01 level, $* *=$ significant at 0.05 level, $*=$

significant at 0.10 level

\section{Conclusions and implications}

The objective of this paper is to investigate the impact of current year audit opinion on next year audit fees and whether this impact will differ with different nature of ownership. The author reviewed prior literature that focused on the determinants of audit fees, the association between audit opinion and audit fees and the association between family ownership and audit fees. 


\section{Dr. Hebatallah Badawy}

The author hypothesized that current year audit opinion is positively and significantly associated with next year audit fees and that the interaction of current year qualified audit opinion and family ownership will have a significant impact on next year audit fees.

Based on a sample of 358 firm-year observations of firms listed on EGX during the period from 2016-2019, the author didn't find significant relationship between current year qualified audit opinion and next year audit fees, however results show that auditors will ask for fee premium to audit the next year financial statements when the auditor issued a qualified audit opinion to family firms.

The findings of this study should be considered in the light of its limitations. One limitation is the lack of a very large data set of audit fees, as although the study covers 180 firms over a period of 4 years, the final sample includes 358 firm year observations, which means that nearly half of the data is unavailable. Second, adding audit related variables, such as auditor switch, expertise, industry specialization and non-audit services to the regression model in future research may add further evidence. Finally, financial companies are excluded from this study due to their different nature of operation and regulatory environment.

Additionally, the author recommends future studies to investigate the effect of different ownership structures on the audit pricing decisions in Egypt. For example, whereas the author focuses on the impact of family ownership on the relationship between current year audit opinion and next year audit fees, it would be interesting to study the effect of institutional and government ownership on the latter relationship. Also, it will be interesting if future research concentrates on the association between other audit related factors, such as auditors' experience level in addition to the type of audit opinion on next year audit fees. Finally, future research may conduct comparative study between Egypt and other developing countries. 


\section{Dr. Hebatallah Badawy}

\section{References}

Akpom, U. (2016), "Multiple Regression Analysis of Company and Audit Firm Characteristics to Predict Audit Fees in Nigeria", $P h D$ Dissertation. North Central University, Arizona, USA. 10156432.

Al-OKaily, J. (2020), "The Effect of Family Control on Audit Fees during Financial Crisis", Managerial Auditing Journal, 35(5): 645-665.

Alzeban, A. and Sawan, N. (2016), "The Relationship between Adherence of Internal Audit with Standards and Audit Fees", Journal of Financial Reporting and Accounting, 14(1): 72-85.

Barua, A., Hossain, M. and Rama, D. (2019), "Financial versus Operating Liability Leverage and Audit Fees", International Journal of Auditing, 23(2): 231-244.

Bedard, J., Gonthier-Besacier, N. and Schatt, A. (2019), "Consequences of Expanded Audit Reports: Evidence from the Justifications of Assessments in France", Auditing: A Journal of Practice \& Theory, 38(3): 23-45.

Ben Ali, C. and Lesage, C. (2013), "Audit Pricing and Nature of Controlling Shareholders: Evidence from France", China Journal of Accounting Research, 6: 21-34.

Ben Ali, C. and Lesage, C. (2014), "Audit Fees in Family Firms: Evidence from U.S. Listed Companies", The Journal of Applied Business Research, 30(3): 807-816.

Bhattacharya, A. and Banerjee, P. (2020), "An Empirical Analysis of Audit Pricing and Auditor Selection: Evidence from India", Managerial Auditing Journal, 35(1): 111-151.

Bicudo de Castro, V., Gul, F., Muttakin, M. and Mihret, D. (2019), "Optimistic Tone and Audit Fees: Some Australian Evidence", International Journal of Auditing, 23: 352-364.

Cahan, S. and Sun, J. (2015), "The Effect of Audit Experience on Audit Fees and Audit Quality", Journal of Accounting, Auditing \& Finance, 30(1): 78-100.

Caneghem, T. (2010), "Audit Fees and the Big4 Fee Premium: Evidence from Belgium”, Managerial Auditing Journal, 25(2): 122-139. 
Dr. Hebatallah Badawy

Cao, L., Li, W. and Zhang, L. (2015), “Audit Mode Change, Corporate Governance and Audit Effort", China Journal of Accounting Research, 8: 315-335.

Caramanis, C. and Spathis, C. (2006), "Auditee and Audit Firm Characteristics as Determinants of Audit Qualifications - Evidence from the Athens Stock Exchange", Managerial Auditing Journal, 21(9): 905-920.

Che Ahmad, A., Shafie, R. and Yusof, N. (2006), “The Provision of NonAudit Services, Audit Services and Auditor Independence", Asian Academy of Management Journal of Accounting and Finance, 2(1): 21-40.

Crucean, A. (2019), “The Information Content of Audit Opinion for Users of Financial Statements", Oradea Journal of Business and Economics, 4(2): 91-101.

Dhaliwal, D., Gleason, C., Heitzman, S. and Melendrez, K. (2008), "Auditor Fees and Cost of Debt", Journal of Accounting, Auditing \& Finance, 23(1): 1-22.

El-Dyasty, M. (2017), “Audit Market in Egypt: An Empirical Analysis”, Working paper. Available at: https://papers.ssrn.com/sol3/papers.cfm?abstract id=3002783

Felix, W. and Kinney, W. (1982), "Research in the Auditor's Opinion Formulation Process: State of the Art", The Accounting Review, 57(2): 245-271.

Firth, M. (2002), "Auditor-Provided Consultancy Services and their Associations with Audit Fees and Audit Opinions", Journal of Business Finance \& Accounting, 29(5\&6): 661-693.

Foster, B. and Shastri, T. (2016), "Determinants of Going Concern Opinions and Audit Fees for Development Stage Enterprises", Advances in Accounting, incorporating Advances in International Accounting, 33: 64-84. Available at: http://dx.doi.org/10.1016/j.adiac.2016.05.001

Francis, J. (1984), "The Effect of Audit Firm Size on Audit Prices", Journal of Accounting and Economics, 6: 133-151. 


\section{Dr. Hebatallah Badawy}

Habib, A. (2013), "A Meta-Analysis of the Determinants of Modified Audit Opinion Decisions", Managerial Auditing Journal, 28(3): 184216.

Hakim, F. Hachicha, E. and Omri, M. (2012), "Investor Reaction to the Information Content of Audit Report for Tunisian Companies: Abnormal Returns and Abnormal Liquidity", International Journal of Business Continuity and Risk Management, 3(3): 244-262.

Harjoto, M. Laksmana, I. and Lee, R. (2015), “The Impact of Demographic Characteristics of CEOs and Directors on Audit Fees and Audit Delay", Managerial Auditing Journal, 30(8/9): 963-997.

Hay, D. (2013), "Further Evidence from Meta-Analysis of Audit Fee Research", International Journal of Auditing, 17: 162-176.

Hay, D., Knechel, W. and Wong, N. (2006), “Audit Fees: A Meta-Analysis of the Effect of Supply and Demand Attributes", Contemporary Accounting Research, 23(1): 141-191.

Ho, J. and Kang, F. (2013), "Auditor Choice and Audit Fees in Family Firms: Evidence from the S\&P 1500", Auditing: A Journal of Practice \& Theory, 32(4): 71-93.

Hossain, S., Yazawa, K. and Monroe, G. (2017), "The Relationship between Audit Team Composition, Audit Fees, and Quality", Auditing: A Journal of Practice \& Theory, 36(3): 115-135.

Jacob, J., Desai, N. and Agarwalla, S. (2019), “An Examination of Factors Driving Big 4 Audit Fee Premiums: Evidence from India's Audit Market", Accounting Horizons, 33(2): 43-58.

Joshi, P. and Al-Bastaki, H. (2000), "Determinants of Audit Fees: Evidence from the Companies Listed in Bahrain", International Journal of Auditing, 4: 129-138.

Kaplan, S., Taylor, G. and Williams, D. (2020), "The Effect of the Type and Content of Audit Reports for Financially Stressed Initial Public Offerings on Information Uncertainty", Auditing: A Journal of Practice \& Theory, 39(1): 125-150.

Khan, A. Hossain, D. and Siddiqui, J. (2011), "Corporate Ownership Concentration and Audit Fees: The Case of an Emerging Economy", 


\section{Dr. Hebatallah Badawy}

Advances in Accounting, incorporating Advances in International Accounting, 27: 125-131.

Khan, A., Muttakin, M.B. and Siddiqui, J. (2015), “Audit Fees, Auditor Choice and Stakeholder Influence: Evidence from a Family-Firm Dominated Economy", The British Accounting Review, 4(4): 304-320.

Kharuddin, K., Basioudis, I. and Hay, D. (2019), "Partner Industry Specialization and Audit Pricing in the United Kingdom", Journal of International Accounting, Auditing \& Taxation, 35: 57-70.

Myoli, T. (2020). "The relationship between audit quality and audit fees", Cape Town: SyndiGate Media Inc. Available at: https://www.bizcommunity.com/Article/196/511/200774.html

Naser, K. and Nuseibeh, R. (2007), "Determinants of Audit Fees: Empirical Evidence from an Emerging Economy", International Journal of Commerce and Management, 17(3): 239-254.

$\mathrm{Ng}, \mathrm{H}$. Tronnes, P. and Wong, L. (2018), "Audit Seasonality and Pricing of Audit Services: Theory and Evidence from a Meta-Analysis", Journal of Accounting Literature, 40: 16-28.

Niemi, L. (2002), "Evidence on Risk Premiums in Audit Fees after Direct Control for Audit Effort", International Journal of Auditing, 6: 37-51.

Nikkinen, J. and Sahlstrom, P. (2003), "Do Auditors Assess the Systematic Market Risk in their Audit Pricing Decisions? International Evidence", Advances in Accounting, 20: 233-244.

Nikkinen, J. and Sahlstrom, P. (2005), "Risk in Audit Pricing: The Role of Firm-Specific Dimensions of Risk", Advances in International Accounting, 18: 141-151.

Paredes, A. and Wheatley, C. (2019), "The Effect of Changing Fiscal Year-Ends on Audit Fees and Audit Quality", Journal of Financial Economic Policy, 12(3): 365-382.

Rani, A. (2018), "Audit Committee Effectiveness: Relationship between Audit Committee Characteristics and Audit Fees and Non-Audit Service Fees", Journal of Commerce and Accounting Research, 7(3): 35-44.

Reid, L., Carcello, J., Li., C. and Neal., T. (2019), "Impact of Auditor Report Changes on Financial Reporting Quality and Audit Costs: 
Evidence from the United Kingdom", Contemporary Accounting Research, 36(3): 1501-1539.

Rusmanto, T. and Waworuntu, S. (2015), "Factors Influencing Audit Fee in Indonesian Publicly Listed Companies applying GCG”, ProcediaSocial and Behavioral Sciences, 172: 63-67.

Shan, Y., Troshani, I. and Tarca, A. (2019), "Managerial Ownership, Audit Firm Size, and Audit Fees: Australian Evidence", Journal of International Accounting, Auditing and Taxation, 35: 18-36.

Simunic, D. (1980), "The Pricing of Audit Services: Theory and Evidence", Journal of Accounting Research, 18(1): 161-190.

Singh, H. and Newby, R. (2010), "Internal Audit and Audit Fees: Further Evidence", Managerial Auditing Journal, 25(4): 309-327.

Smith, T., Higgs, J. and Pinsker, R. (2019), "Do Auditors Price Breach Risk in Their Audit Fees?", Journal of Information Systems, 33(2): 177-204.

Tahinakis, P. and Samarinas, M. (2016), "The Incremental Information Content of Audit Opinion", Journal of Applied Accounting Research, 17(2): 139-169.

Tee, C. (2018), "Family Firms, Political Connections and Audit Fees: Evidence from Malaysian Firms", Managerial Auditing Journal, 33(6/7): 612-632.

Xiao, T., Geng, C. and Yuan, C. (2020), "How Audit Effort Affects Audit Quality: An Audit Process and Audit Output Perspective", China Journal of Accounting Research, 13: 109-127.

Yen, J-C., Lim, J., Wang, T. and Hsu, C. (2018), “The Impact of Audit Firm's Characteristics on Audit Fees Following Information Security Breaches". Journal of Accounting and Public Policy, Available at: http://doi.org/10.1016/j.jaccpubpol.2018.10.002.

Zhang, J. (2018), "Accounting Comparability, Audit Effort, and Audit Outcomes", Contemporary Accounting Research, 35(1): 245-276. 


\title{
Dr. Hebatallah Badawy
}

\section{العلاقة بين رأى مراقب الحسابات للسنة الحالية وتسعير مهمة المراجعة للسنة \\ القادمة: هل تؤثر الملكية العائلية على هذه العلاقة؟}

\author{
إعداد \\ د. هبة الله عبد السلام محمود بدوي \\ كلية التجارة - جامعة الإسكندرية \\ كلية الأعمال الدولية والإنسانيات ـ الجامعة المصرية اليابانية للعلوم و التكنولوجيا \\ ملخص البحث \\ بهدف البحث إلى اختبار العلاقة بين رأى مر اقب الحسابات للسنة الحالية وتسعير مهمة

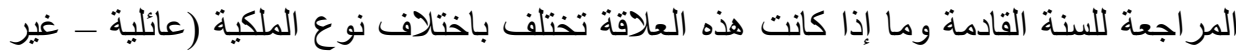

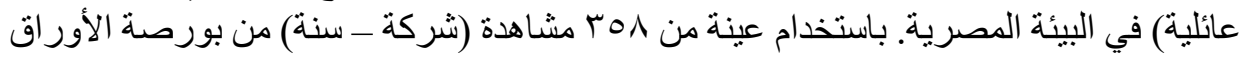

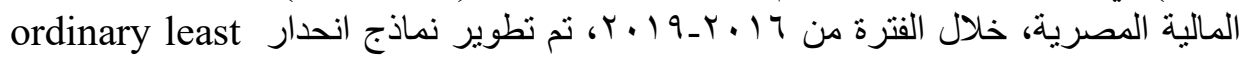

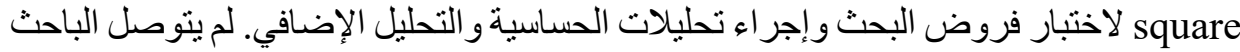

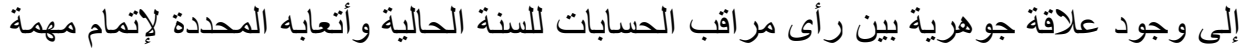

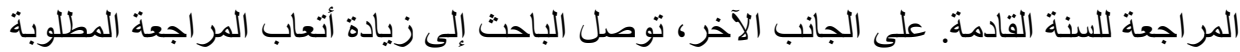

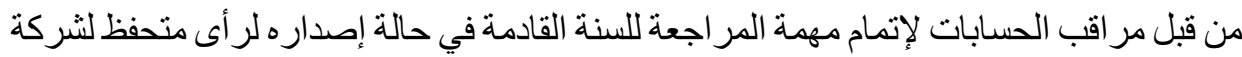

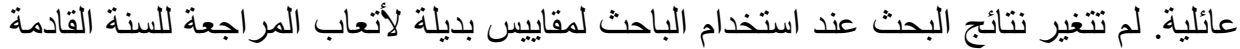

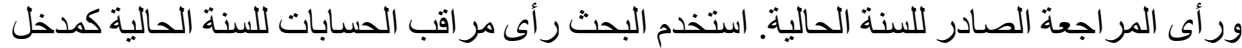

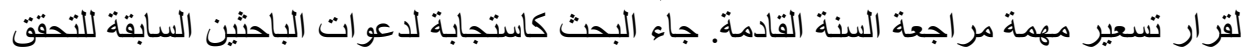

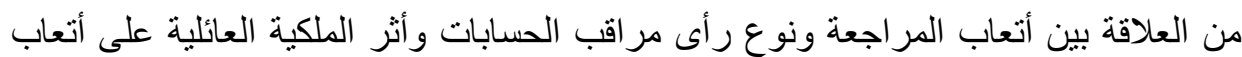

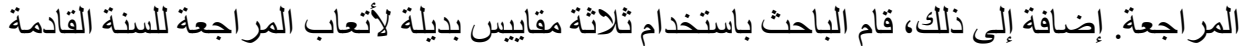

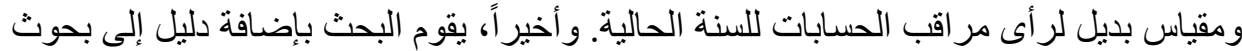 \\ حوكمة الشركات في الدول النامية. \\ الكلمات المفتاحية: أتعاب المر اجعة، رأى المر اجعة، الملكية العائلية، مصر
}

